of the vesicles became pustular, and the fotor was more marked than in many cases of small-pox. Desiccation was not complete until about Jan. 31st. The eruption appeared on the palms of the hands and the soles of the feet but the amount in these situations relative to that which appeared on the arms and legs was very much less. The difference was well marked, and this fact, together with the rapidity with which the eruption developed and passed through its various stages, and the successive crops which appeared, as well as the absence of premonitory symptoms, removed all doubt as to the true nature of the disease.

Halifax.

\section{A NOTE ON THE VALUE OF MASSAGE OF THE STOMACH IN FLATULENT DYSPEPSIA.}

By H. Statham, M.B., B.C. Cantab.,

IATE HOUSE SURGEON TO ST. BARTHOLOMEW'S HOSPITAL.

A GENTLEMAN of $\mathrm{my}$ acquaintance has for many years suffered from attacks of flatulent dyspepsia at intervals varying from a few days to several months. These attacks come on quite suddenly with great oppression in the epigastrium, a general feeling of malaise, profuse sweating, and a small and rapid pulse, ranging from 120 to 150 . The duration of the attacks varies from an hour or two up to 12 hours or more, and they cease spontaneously as suddenly as they begin. Nothing in the way of drugs or applications appears to have any effect in bringing about the termination of the attack. A short time ago I tried massage of the stomach during one of these attacks, the massage being of the character of somewhat forcible kneading movements. Almost at once gurgling sounds could be heard from time to time as if the contents of the stomach were passing into the duodenum, and within ten minutes the attack was at an end. This treatment has been tried on the same patient in two subsequent attacks, once by myself and once by a friend, with an equally favourable result on each occasion. I would appear from this that the attacks above described are brought about by a paralytic distension of the stomach due to gases produced by a fermentative process, and that the massage by stimulating the organ to action causes its contents to be passed on into the bowel. This view is supported by the fact that on one of the above occasions after the attack had been brought to an end by massage very large quantities of gas were passed per anum.

Lymington, Hants.

\section{9) attirtor}

\section{HOSPITAL PRACTICE, BRITISH AND FOREIGN.}

Nulla autem est alia pro certo noscendi via, nisi quamplurimas $t$ morborum et dissectionum historias, tum aliorum tum proprias Morb., lib.iv., Procemium.

\section{EAST SUFFOLK AND IPSWICH HOSPITAL.}

A CASE OF "VOLVULUS OF THE CACUM" PRODUCED BY THE TRACTION OF AN INFLAMED APPENDIX.

(Under the care of Dr. E. HoLLIS.)

FOR the notes of the case we are indebted to Mr. S. Clifford Hayman, house surgeon.

The patient was a delicate looking woman, aged 50 years. For one week before admission to the East Suffolk and Ipswich Hospital she hac suffered indefinite pain in the abdomen and had romited about once a day, but she was not too ill to keep about the house. There was also some constipation, which led her to take some castor oil on the morning of the fifth day. This was followed by diarrhœa in the evening. The next morning she awoke with severe pain in the lower part of the abdomen and she began to vomit frequently. The symptoms not abating she sent for Dr. E. Hollis. Bismuth was prescribed but after 48 hours it became evident that there was intestinal obstruction and she was sent into hospital for operation. When seen in the ward the patient looked fairly comfortable though a little pale and she only complained of slight pain in the lower part of "her body," not so severe as it had been, and said that she felt sick. Her temperature was $96^{\circ} \mathrm{F}$., her pu'se was 88 and feeble, and her respirations were 32 per minute. The tongue was slightly furred. Examination of the chest behind was postponed. The abdomen was much distended, the distension being markedly of the small.gut type. The abdominal wall was soft and moved slightly on respiration. There was some general tenderness but it was most marked in the region of the appendix. No definite swelling could be palpated anywhere and the percussion note was tympanitic. Sounds of peristalsis were heard in normal amount. Rectal examination yielded no useful information. The urine had a specific gravity of 1035 , contained a large quantity of albumin, and gave the tests for sugar and diacetic acid.

It was decided to operate immediately and the patient was anæsthetised at 5.50 P.M. The abdomen having been opened by an incision in the midale line below the umbilicus a tense cystic swelling presented which much resembled an ovarian cyst but proved to be an enormously distended cæcum. A trocar was inserted and a large amount of gas together with eight ounces of fluid (black from the bismuth administered) was evacuated. The small intestine was likewise distended; not so the colon. The cæcum was next drawn out and its attachments were explored. It was found that it had undergone rotation " clockwise" through half a circle, complete intestinal obstruction being produced by occlusion of its lumen at either end. At its attachment to the posterior abdominal wall on its outer aspect and helping in the constriction was found a densely adherent appendix two and a half inches in length running upwards and backwards to a point just above the cæco-colic junction, where its apex was held by a fibrous band of no very recent formation. It was freed, cut off short, and its base inverted into the cæcum. The volvulus was next unwound, a small amount of serous fluid was sponged out of the pelvis, and the abdominal wound closed. The patient only vomited once after returning to the ward and passed a comfortable night. The following morning there was a slight action of the bowels and all appeared to be going well until the next day at noon. She was then noticed to be getting drowsy. Her pulse was 100 and weaker, her respirations had risen to $45^{\circ}$ per minute, and there was a little cedema of the face. Crepitations were audible all over the right lung behind. Stimulants were administered but the patient became quickly more drowsy and restless, so that by 5 P.M. she could not be roused. Her pupils were moderately dilated and her temperature, subnormal through. out, fell steadily. The usual treatment for uræmia was carried out but the patient died at 8.30 P.M.

Necropsy. - A post-mortem examination showed that the operation had quite removed the obstruction and there was no peritonitis. A meso-cacum was present and it was found very easy to reproduce the volvulus. The kidneys were granular and there was advanced tuberculosis of the right lung.

Kemarks by Mr. HAYMAN.-There is no doubt that the above is one of those cases, sometimes described in book but so very rarely seen, where an inflamed appendix has, by contraction and traction, produced a volvulus of the cæcum. I am indebted to Dr. Hollis for permission to publish the case.

\section{MELBOURNE HOSPITAL.}

(1) A CASE OF COMPLETE ROTATION OF A PREGNANT UTERUS (2) TRAUMATIC RUPTURE OF A HYDATID CYST IN THE LEFT LOBE OF THE LIVER ; AND (3) HYDATID OF THE LIVER WITH PASSAGE OF SMALL CYSTS

THROUGH BILE-DUUTS, SIMULATING GALL-STONES.

(Under the care of Mr. G. A. SYME.)

CASE 1. Complete rotation of a pregnant uterus.-The patient, a married woman, aged 26 years, was admitted into the Melbourne Hospital on May 29th, 1905. She was collapsed and profoundly blanched and complained of severe pain in the abdomen, which had come on suddenly three days previously. She believed herself to be six months pregnant. There had been no previous symptoms and she had met with no injury. She had been married four years and had two healthy children. She had no bleeding from the 